\title{
THE DISINFECTION OF THE ORAL MUCOSA WITH CRYSTAL VIOLET AND BRILLIANT GREEN ${ }^{1}$
}

\author{
C. COLEMAN BERWICK
}

George William Hooper Foundation for Medical Research and Research Laboratories of the Dental Department of the University of California, San Francisco, California

\section{CONTENTS}

I. Introduction $\ldots \ldots \ldots \ldots \ldots \ldots \ldots \ldots \ldots \ldots \ldots \ldots \ldots \ldots \ldots \ldots \ldots \ldots \ldots \ldots \ldots, 22$

II. The general plan, method, and results of the author's experiments....... 23

1. First series. Results with alcohol, acetone, ether and tincture of iodine... 23

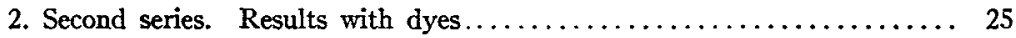

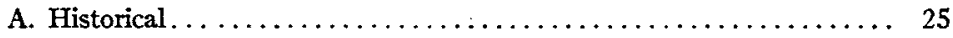

B. Technical . . . . . . . . . . . . . . . 26

C. Results with brilliant green (saturated solution in alcohol) . . . . . 27

D. Results with brilliant green ( 1 per cent solution in 50 per cent alcohol) 28

E. Results with brilliant green and crystal violet in solution together (1 per cent of each in 50 per cent alcohol) applied for 1.5 minute... 28

F. Results of tests similar to those in the last preceding section (E), with additional bacteriological precautions ............. 30

G. Results of tests with brilliant green and crystal violet in solution together (1 per cent of each in aqueous solution) compared with hydroquinone ( 1 per cent aqueous solution) $\ldots \ldots \ldots \ldots \ldots \ldots \ldots \ldots \ldots$

H. Results of a repetition of the tests with brilliant green and crystal violet in solution together in alcohol (section $\mathrm{E}$ ), with an extension of the period of application to the gum (from 1.5 minute) to 2 minutes............................... 33

I. Results of a repetition of the tests with brilliant green and crystal violet together in alcohol, in the last preceding section $(\mathrm{H})$, after previous thorough flushing of the mouth with an alkaline wash and brushing of the teeth $\ldots \ldots \ldots \ldots \ldots \ldots \ldots \ldots \ldots \ldots \ldots$

3. General discussion of the results of the first two series of tests ....... 38

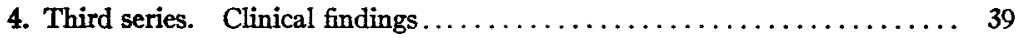

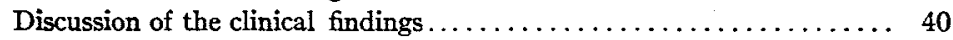

III. Summary of general conclusions $\ldots \ldots \ldots \ldots \ldots \ldots \ldots \ldots \ldots \ldots \ldots \ldots \ldots, 41$

IV. Literature cited $\ldots \ldots \ldots \ldots \ldots \ldots \ldots \ldots \ldots \ldots \ldots \ldots \ldots \ldots \ldots \ldots \ldots$

1 According to Churchman (Journal of the American Medical Association, January 17, 1920), the term "disinfection" when applied to the action of dyes, is a misnomer. He prefers the term "bacteriostasis," not only from an etymological point of view, but also from the standpoint of accuracy of description. We believe, with Churchman, that the term "bacteriostasis" is a more suitable one than "disinfection," in this relation. 


\section{INTRODUCTION}

In the study of the bacteriology of apical and periapical infections, there is great variation in the cultural technique of different investigators. Since the relative value of the results obtained by different experimenters depends upon an unbroken chain of aseptic procedures in each case, it is important to ascertain what technical conditions must be established for the sterilization of the oral mucosa, and also to determine the relative efficiency for this purpose of the available antiseptics. From a consideration of some of the many methods used to obtain material for bacteriological study, especially material in the vicinity of the gingival border, it is apparent that the technique described is not free from criticism. To such an extent does this fact obtain that opinions, rather than scientific facts, appear to have influenced, if not actually to have served as a foundation for, the results reported.

Gilmer and Moody (7) state that "the field to be incised was made as nearly aseptic as possible by thorough washing with 50 per cent alcohol." Schamberg (21) says: "We removed the tooth and from it got a pure culture of Streptococcus viridans." Hartzell and Henrici (10) state that it is "almost an impossibility to extract a healthy tooth and find it free from viridans unless that tooth has been rendered free from bacteria by rubbing the tooth with iodine and subsequently burning the gingival field with the actual cautery." Head and Roos (11) "washed the neck of the tooth with alcohol until it was considered to be practically free from living bacteria. It was then painted with tincture of iodine three times at short intervals so that it would be practically impossible for any organisms on the neck of the tooth to be alive." Howe (12) uses two solutions: (a) silver nitrate, $3 \mathrm{gm}$.; distilled water, $1 \mathrm{cc}$; ammonium hydroxid (28 per cent), 2.5 cc. and (b) formalin (25 per cent). These two solutions, mixed, make everything absolutely sterile, according to Howe, and destroy every type of microörganism. Rosenow (20) does not give any technique for obtaining his material but states that the danger of contamination, with the mouth flora, in the removal of teeth, "becomes slight in proper hands." 
Kelsey (13) tested a great variety of substances in the culture of organisms to ascertain their value as disinfectants. He -concluded that "tincture of iodine is the most useful disinfectant for use in the mouth in treating lesions where strepto-bacillus is present." Kelsey gives no clinical evidence with the results of his laboratory work, but assumes that his laboratory findings apply in vivo as well as in vitro.

II. THE GENERAL PLAN, METHOD, AND RESULTS OF THE AUTHOR'S EXPERIMENTS

In view of the uncertainty revealed by these quoted statements, we sought to find an antiseptic which would be efficient and yet which would be relatively innocuous to the normally sensitive mucous membrane of the oral cavity. In the light of the suggestion by Meyer (19), the problem was attacked from a chemotherapeutic view-point. Accordingly, observations were made upon the therapeutic and chemical effects produced by various drugs ordinarily used in clinical practice, as well as upon suggested changes in concentration of the antiseptics. The mode of application was the same in all instances, namely, by means of cotton pellets moistened with the different fluids. Application was always made on the gum of the maxilla near the frenum.

\section{First series. Results with alcohol, acetone, ether, and tincture of iodine}

The results obtained with alcohol, acetone, ether, tincture of iodine, and dilute tincture of iodine, are summarized in table 1. It will be noted that, in the use of either 60 per cent alcohol or 95 per cent alcohol, there was variation in the degree of dehydration of the gum. When the application of alcohol was followed, in turn, first by ether, second by acetone, finally by a mixture of the three in equal proportions, the results varied in the degree of dehydration induced, as well as in the degree of sterility of the tissue. In each case there was a definite dehydrating action on the gum by the alcohol, an effect that renders the use of alcohol of these strengths unsuitable for all practical purposes of oral disinfection, even though in some tests 
sterility was obtained in 100 per cent of the tests. Tincture of iodine, also dilute tincture of iodine $(1: 10)$, was used. With the former sterility was obtained, but only at the expense of blistering the gum surface. With the latter practically no sterility was obtained.

TABLE 1

Data on the efficiency of alcohol, ether, acetone, and iodine in efforts to obtain sterility in the buccal cavity.

\begin{tabular}{|c|c|c|c|c|}
\hline DRUGS TESTED & $\begin{array}{l}\text { PERIOD OF } \\
\text { APPLICATION }\end{array}$ & $\mid \begin{array}{c}\text { NOMBER } \\
\text { OF } \\
\text { CASES }\end{array}$ & $\begin{array}{c}\text { BACTERIOLOGICAI } \\
\text { RESULT }\end{array}$ & ETPECTS ON THE GUMS \\
\hline & minutes & & & \\
\hline Alcohol, 95 per cent & 2 & 5 & $\begin{array}{c}\text { Sterility in but } \\
\text { one case }\end{array}$ & Gums badly dehydrated \\
\hline Alcohol, 95 per cent & 3 & 5 & $\begin{array}{l}\text { Sterility in four } \\
\text { cases }\end{array}$ & Gums badly dehydrated \\
\hline Alcohol, 60 per cent & 2 & 7 & No sterility & Gums not dehydrated \\
\hline Alcohol, 60 per cent & 3 & 5 & No sterility & $\begin{array}{l}\text { Gums slightly dehy- } \\
\text { drated }\end{array}$ \\
\hline $\begin{array}{l}\text { Alcohol (95 per cent), } \\
\text { ether, and acetone, in } \\
\text { one-two-three-order }\end{array}$ & $\begin{array}{r}\text { 1, for each } \\
\text { substance }\end{array}$ & 5 & No sterility & Gums badly dehydrated \\
\hline $\begin{array}{l}\text { Alcohol (95 per cent) } \\
\text { ether, and acetone, in } \\
\text { one-two-three order }\end{array}$ & $\begin{array}{r}2, \text { for each } \\
\text { substance }\end{array}$ & 5 & $\begin{array}{c}\text { Sterility in but } \\
\text { two cases }\end{array}$ & Gums badly dehydrated \\
\hline $\begin{array}{l}\text { Alcohol (95 per cent), } \\
\text { ether, and acetone, } \\
\text { mixed in equal pro- } \\
\text { portions }\end{array}$ & 2 & 4 & $\begin{array}{c}\text { Sterility in but } \\
\text { two cases }\end{array}$ & Gums badly dehydrated \\
\hline Tincture of iodine & 1 & 3 & $\begin{array}{r}\text { Sterility in } \\
\text { three cases }\end{array}$ & $\begin{array}{l}\text { Gums dehydrated and } \\
\text { "burned" }\end{array}$ \\
\hline $\begin{array}{l}\text { Tincture of iodine, di- } \\
\text { luted with water } \\
(1: 10)\end{array}$ & 1 & 3 & No sterility & $\begin{array}{l}\text { Gums apparently not } \\
\text { "burned" }\end{array}$ \\
\hline $\begin{array}{l}\text { Tincture of iodine, di- } \\
\text { luted with water } \\
(1: 10)\end{array}$ & 2 & 3 & $\begin{array}{l}\text { Sterility in one } \\
\text { case }\end{array}$ & Gums "burned" \\
\hline Total. & & 45 & $\begin{array}{l}\text { Sterility in } \\
\text { thirteen } \\
\text { cases }\end{array}$ & \\
\hline
\end{tabular}

Seelig and Gould (22) as early as 1911, definitely proved that alcohol is a good antiseptic in direct proportion to its concentration. The results of our experiments show that the utility of alcohol as an antiseptic, in the strengths referred to (60 per cent and 95 per cent), 
is impaired, for oral purposes, by its undesirable dehydrating action on the mucous membranes-one of the effects we have endeavored to overcome. Such dehydration of the oral mucous membranes is objectionable because blistering or burning of the gum follows it, and the ensuing lowered local resistance and subsequent superficial necrosis delay the process of healing and favor the further ingress of microörganisms.

\section{Second series. Results with dyes}

\section{A. Historical}

Leitch (14) used brilliant green in dilute aqueous solution. He found it non-toxic to normal tissue, though antiseptic in action. He also observed that this dye inhibited the growth of staphylococci to a greater extent than it did that of streptococci. The same dye was used, as a paste for injection into wounds, by Short (23) who obtained equally good results. Browning (5) found that brilliant green, 1:2000 in water, is five hundred times as toxic for staphylococci as is Dakin's solution. He also found (4) that it stimulates healthy granulation tissue as well as acts as an antiseptic. Webb (24) and Ligot (15) obtained similar results with the dye.

Browning $(2,1,3)$ found that a mixture of crystal violet and brilliant green kills gram-positive cocci chiefly, whereas B. coli, resists its action to a greater extent. He used a solution of 1 per cent of crystal violet and 1 per cent of brilliant green, together in 50 per cent alcohol, with excellent results, and suggested the use of the dye as an antiseptic for mucous membranes.

Graham-Smith (8) found that the toxicity or inhibitory power of crystal violet, as well as various flavines [acriflavine and proflavine, which are acridine dyes, derivatives of acridine, a base found in coal tar (9)], depends to a great extent upon the degree of alkalinity of the solution to which the dye is added-that is, the greater the alkalinity, to a certain degree, the greater is the antiseptic power. For example, crystal violet inhibits the growth of Staphylococcus aureus under the conditions indicated on the next page: ${ }^{2}$

${ }^{2}$ The ratio signifies, in each case, that one part of the dye in the indicated number of parts of aqueous solution, with the reaction stated, is the greatest dilution of the dye, in the particular circumstances, that will completely prevent growth of the organism named. 


\begin{tabular}{|c|c|c|c|}
\hline $\begin{array}{c}0.15 n / 10 \text { hydrochloric acid } \\
1: 1,500,000\end{array}$ & $\begin{array}{c}0.08 n / 10 \text { sodium hydroxid } \\
1: 3,500,000\end{array}$ & \multicolumn{2}{|c|}{$0.58 \mathrm{n} / 10$ sodium hydroxid } \\
\hline Dye lested and medium used & \multicolumn{3}{|c|}{ Organisms studied } \\
\hline Crystal violet & Staphylococcus & B. coli & B. pyocyaneus \\
\hline 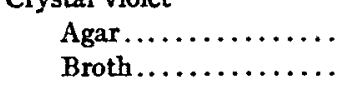 & 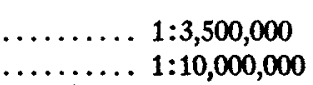 & $1: 10,000$ & $1: 10,000$ \\
\hline Brilliant red & & & \\
\hline Agar... & $\ldots 1: 3,250,000$ & $1: 1,000$ & $1: 1,000$ \\
\hline Broth.... & $1: 500,000$ & $1: 10,000$ & $1: 10,000$ \\
\hline Quinone & & & \\
\hline Agar... & $\ldots \ldots \ldots \ldots 1: 10,000$ & $1: 95,000$ & $1: 30,000$ \\
\hline Broth... & $\ldots \ldots 1: 60,000$ & $1: 100,000$ & $1: 10,000$ \\
\hline Hydroquinone & & & \\
\hline Agar.... & $\ldots \ldots \ldots 1: 60,000$ & $1: 40,000$ & $1: 10,000$ \\
\hline Broth......... & ...... 1:20,000 & $1: 20,000$ & $1: 10,000$ \\
\hline Homoflavine & & & \\
\hline Agar......... & $\ldots \ldots 1: 14,000$ & $1: 9,000$ & $1: 2,000$ \\
\hline Broth.. & ..... 1:300,000 & $1: 250,000$ & $1: 30,000$ \\
\hline
\end{tabular}

Thus we note that in alkaline media, the dye tends to be more efficient as an antiseptic, at least so far as Staphylococcus aureus is concerned. According to Marshall (18) the hydrogen ion concentration of saliva varies not only in different individuals, but also in the same individual from time to time. This variation, as has been pointed out by other investigators, may be due to nervous impulses or reflexes which appear to be correlated with such factors as diet, and with the pathology of the oral and gastric mucosae and the teeth.

A small series of experiments was undertaken by us to determine the hydrogen ion concentration $\left(\mathrm{P}_{\mathrm{n}}\right)$ of saliva by the colorimetric method (with phenolsulfonephthalein as the indicator), according to the procedures of Clark and Lubs (6) and of MacLeod (17), with the following results for $P_{z}$ in six different specimens: $7.3,7.3,7.8,7.6$, 7.3, 7.5; average, 7.43 .

The average for $P_{n}, 7.43$, indicates a fair degree of alkalinity, which appears to be sufficient to enhance the value of the dye (crystal violet) as an antiseptic.

\section{B. Technical}

The solutions to be tested were applied to the gum of the upper jaw between the mucosa of the lip and of the gum beside the frenum, because of the ease with which one may eliminate saliva from the field 
by packing with sterile cotton. The dye was applied by means of pledgets of cotton saturated with the dye solution of various strengths and for different periods. Bacterial cultures were made in glucoseveal bouillon, and on glucose-blood agar slants or plates, by the use of sterile swabs, kept in the individual test tubes in which they were sterilized.

\section{Results with brilliant green (saturated solution in alcohol)}

A saturated solution of brilliant green ${ }^{3}$ in 95 per cent alcohol or in 60 per cent alcohol, was applied, as indicated above, and the swab cultured after one minute of application. A second test was subse-

TABLE 2

Data on the efficiency of alcoholic solutions of brilliant green in efforts to obtain sterility in the buccal cavity

\begin{tabular}{|c|c|c|c|c|}
\hline SOLUTION OF BRILLIANT GREEN & $\begin{array}{l}\text { PERIOD OF } \\
\text { APPIICA- } \\
\text { TION }\end{array}$ & $\begin{array}{l}\text { NUABER } \\
\text { OF } \\
\text { CASES }\end{array}$ & $\begin{array}{l}\text { BACTERIOLOGI- } \\
\text { CAL RESULT }\end{array}$ & ERPECTS ON TEE GUZS \\
\hline & minute & & & \\
\hline $\begin{array}{l}\text { Saturated, in } 95 \text { per cent alco- } \\
\text { hol }\end{array}$ & 1 & 5 & $\begin{array}{l}\text { Sterility in } \\
\text { five cases }\end{array}$ & Gums badly dehydrated \\
\hline $\begin{array}{l}\text { Saturated, in } 60 \text { per cent alco- } \\
\text { hol }\end{array}$ & 1 & 5 & $\begin{array}{l}\text { Sterility in } \\
\text { five cases }\end{array}$ & $\begin{array}{l}\text { Gums only slightly de- } \\
\text { hydrated }\end{array}$ \\
\hline $\begin{array}{l}\text { Saturated, in } 95 \text { per cent alco- } \\
\text { hol }\end{array}$ & 1 & 5 & $\begin{array}{l}\text { Sterility in } \\
\text { five cases }\end{array}$ & $\begin{array}{l}\text { Gums very badly de- } \\
\text { hydrated }\end{array}$ \\
\hline $\begin{array}{l}\text { Followed by washing with } \\
95 \text { per cent alcohol }\end{array}$ & 0.5 & & & \\
\hline $\begin{array}{l}\text { Saturated, in } 60 \text { per cent alco- } \\
\text { hol }\end{array}$ & 1 & 5 & $\begin{array}{l}\text { Sterility in } \\
\text { five cases }\end{array}$ & $\begin{array}{l}\text { Gums only slightly de- } \\
\text { hydrated }\end{array}$ \\
\hline $\begin{array}{l}\text { Followed by washing with } \\
60 \text { per cent alcohol }\end{array}$ & 0.5 & & & \\
\hline \multicolumn{2}{|l|}{ Total. } & 20 & $\begin{array}{l}\text { Sterility in } \\
\text { twenty } \\
\text { cases }\end{array}$ & \\
\hline
\end{tabular}

quently made in which the excess of the dye remaining on the gum was removed by washing with alcohol of the same strength as that used originally to dissolve the dye. The part so treated was then tested for sterility in the usual manner. Sterility was obtained in all cases,

Thus far only Grübler's dyes have been used in this work. 
but the alcohol exerted too great a dehydrating action upon the mucous membrane to permit of its routine application. The results are summarized in table 2 .

D. Results with brilliant green (1 per cent solution in 50 per cent alcohol)

In this group of tests the technique was similar to that of the tests in section C, except that we used a 1 per cent solution of brilliant green in 50 per cent alcohol. Sterility was obtained in 78.5 per cent of the cases and there was only a slight degree of harmful effect of the alcohol upon the gums. The results are shown in table 3.

TABLE 3

Additional data on the efficiency of brilliant green in alcoholic solution in efforts to obtain sterility in the buccal cavity

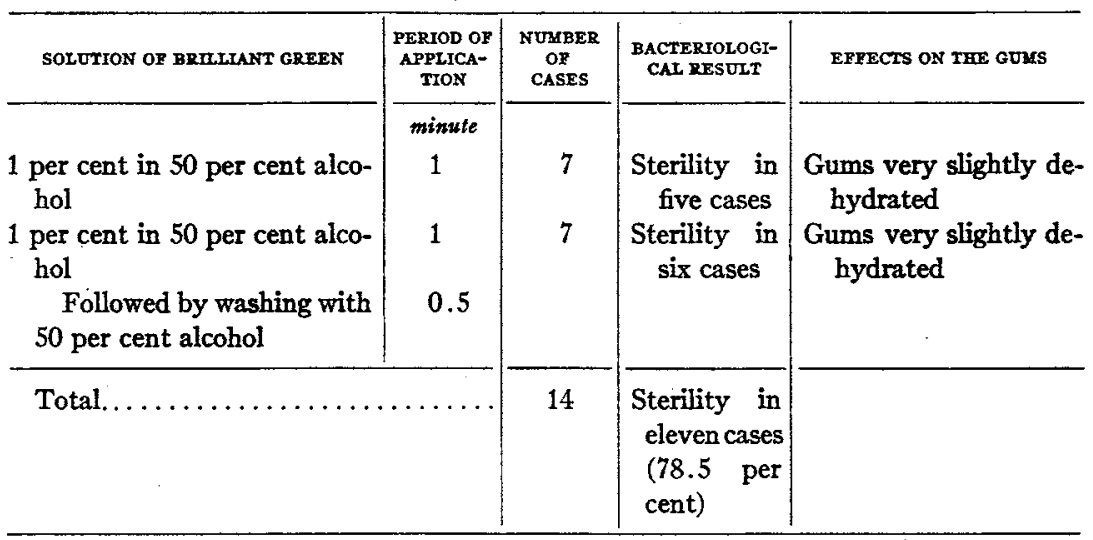

E. Results with brilliant green and crystal violet in solution together (1 per cent of each in 50 per cent alcohol) applied for 1.5 minute

In this series of cases, the dye employed was a mixture of brilliant green and crystal violet, 1 per cent of each in 50 per cent alcohol, applied for 1.5 minute. The action of the dye upon the organisms normally present was measured, in this instance, by taking cultures (a) from the gum-surface before applying the dye, and (b) from the relative numbers of organisms computed to be present in smears of the broth culture, as well as (c) from the number of colonies on plates of enrichment media. 
TABLE 4

Data on the efficiency of crystal violet and brilliant green together ( 1 per cent of each), in 50 per centalcohol, in efforts to obtain sterility in the buccal cavity. Period of application to the gum: 1.5 minute. (In this, and succeeding tables, the signs, $x$, $x x$, and $x x x$, indicate the relative numbers of organisms in the cultures. Where no such sign is recorded, a pure culture was involved)

\begin{tabular}{|c|c|c|c|c|}
\hline$\underset{\text { NUMBER }}{\text { CASE }}$ & $\begin{array}{l}\text { ORGANISMS ON THE GUM-SURFACE BETORE } \\
\text { THE DYE WAS APPLIED }\end{array}$ & $\begin{array}{l}\text { BESULTS ATTER } \\
\text { TEE DYE } \\
\text { SOLUITON HAD } \\
\text { BEEN APPLIED }\end{array}$ & $\begin{array}{c}\text { RESULTS ATTER } \\
\text { THE EXCESS } \\
\text { OF TEE DYE EAD } \\
\text { BEEN REMOVED } \\
\text { BY WASHING } \\
\text { WTTH ALCOHOL }\end{array}$ & TYPE OF CASE \\
\hline 17 & $\begin{array}{l}\text { Streptococci xxx } \\
\text { Diplostreptococci } \mathbf{x}\end{array}$ & $\begin{array}{l}\text { Sterile in } 48 \\
\text { hours }\end{array}$ & Same & Pyorrhea \\
\hline 18 & $\begin{array}{l}\text { Diplostreptococci } x \times x \\
\text { Streptococci, short chain } x \\
\text { Staphylococcus albus } x\end{array}$ & $\begin{array}{c}\text { Sterile in } 48 \\
\text { hours }\end{array}$ & Same & Pyorrhea \\
\hline 19 & $\begin{array}{l}\text { B. acidophilus } x \times x \\
\text { Diplostreptococci } \mathbf{x x} \\
\text { Streptococci } x\end{array}$ & $\begin{array}{l}\text { Diplostrepto- } \\
\text { cocci } \\
\text { present }\end{array}$ & Same & Pyorrhea \\
\hline 20 & $\begin{array}{l}\text { Diplostreptococci } \mathrm{xxx} \\
\text { Streptococci } \mathrm{xx} \\
\text { Staphylococcus albus } \mathrm{x}\end{array}$ & $\begin{array}{l}\text { Sterile in } 36 \\
\text { hours }\end{array}$ & Same & Pyorrhea \\
\hline 21 & $\begin{array}{l}\text { Diplostreptococci xxx } \\
\text { Staphylococcus albus } x \\
\text { Streptococci } x\end{array}$ & $\begin{array}{c}\text { Sterile in } 36 \\
\text { hours }\end{array}$ & Same & Pyorrhea \\
\hline 22 & $\begin{array}{l}\text { Diplostreptococci } x x x \\
\text { Streptococci } x\end{array}$ & $\begin{array}{c}\text { Sterile in } 36 \\
\text { hours }\end{array}$ & Same & Pyorrhea \\
\hline 23 & $\begin{array}{l}\text { Diplostreptococci xxx } \\
\text { Staphylococcus albus } \mathbf{x}\end{array}$ & $\begin{array}{c}\text { Sterile in } 36 \\
\text { hours }\end{array}$ & Same & Pyorrhea \\
\hline 24 & $\begin{array}{l}\text { Diplostreptococci xxx } \\
\text { Streptocócci } x\end{array}$ & $\begin{array}{c}\text { Sterile in } 36 \\
\text { hours }\end{array}$ & Same & Pyorrhea \\
\hline 25 & $\begin{array}{l}\text { Streptococci, long chain } x \times x \\
\text { Staphylococcus albus } x \times x\end{array}$ & $\begin{array}{l}\text { Streptococci, } \\
\text { long chain } \\
\text { present }\end{array}$ & Same & Pyorrhea \\
\hline 26 & $\begin{array}{l}\text { Streptococci xxx } \\
\text { Diplostreptococci } x\end{array}$ & Sterile & Same & Pyorrhea \\
\hline 27 & $\begin{array}{l}\text { Staphylococcus albus } x x x \\
\text { Streptococci, short chain } x x x\end{array}$ & $\begin{array}{l}\text { Sterile in } 48 \\
\text { hours }\end{array}$ & Sạme & Pyorrhea \\
\hline
\end{tabular}




\begin{tabular}{|c|c|c|c|c|}
\hline $\begin{array}{c}\text { CASE } \\
\text { NUNBER }\end{array}$ & $\begin{array}{l}\text { ORGANISMS ON THE GUM-SURPACE BEPORE } \\
\text { THE DYE WAS APPLED }\end{array}$ & $\begin{array}{l}\text { RESULTS AFTER } \\
\text { THE DYE } \\
\text { SOLUTION HAD } \\
\text { BEEN APPLEDD }\end{array}$ & $\begin{array}{l}\text { RESULTS AFTER } \\
\text { THE EXCES } \\
\text { OF THE DYE HAD } \\
\text { BEEN REMOVD } \\
\text { BY WASEING } \\
\text { WITH AICOHOL }\end{array}$ & TYPE OP CASE \\
\hline 28 & $\begin{array}{l}\text { B. acidophilus } x x \\
\text { Streptococci, short chain } x x \\
\text { Staphylococcus albus } x\end{array}$ & $\begin{array}{c}\text { Gram-rod- } \\
\text { like or- } \\
\text { ganism } \\
\text { present }\end{array}$ & Same & Pyorrhea \\
\hline 29 & $\begin{array}{l}\text { Diplostreptococci } \mathrm{xxx} \\
\text { Streptococci, short chain } \mathrm{xx}\end{array}$ & $\begin{array}{c}\text { Sterile in } 48 \\
\text { hours }\end{array}$ & Same & Pyorrhea \\
\hline 30 & $\begin{array}{l}\text { Streptocacci, long chain } x x \\
\text { Staphylococcus aureus } x\end{array}$ & $\begin{array}{c}\text { Sterile in } 36 \\
\text { hours }\end{array}$ & Same & Pyorrhea \\
\hline
\end{tabular}

Total number of cases, 14 . Sterility in the number of cases indicated below:

$|\quad|$\begin{tabular}{c|c}
11 cases; 78.5 \\
per cent
\end{tabular}$\left|\begin{array}{c}10 \text { cases; } 75 \\
\text { per cent }\end{array}\right|$

By comparing these results with those obtained after swabbing the gum-surface with the dye, and after the subsequent removal of the excess of the dye with 50 per cent alcohol, a direct determination of the sterilizing action of the fluids could be made. The cases were all diagnosed as pyorrheal. Sterility was obtained in 75 per cent of them. The results are given in table 4.

F. Results of tests similar to those in the last preceding section (E), with additional bacteriological precautions

In addition to the previous precautions and technique, this series of experiments was further controlled by planting the last swab, used in culturing the gum-surface, in glucose-veal broth. In this series of tests we obtained sterility in 80 per cent of the cases. The findings are given in table 5 . 
TABLE 5

Additional data on the efficiency of crystal siolet and brilliant green together ( $I$ per cent of each), in 50 per cent alcohol, in efforts to obtain sterility in the buccal cavity. Period of application to the gum: 1.5 minute.

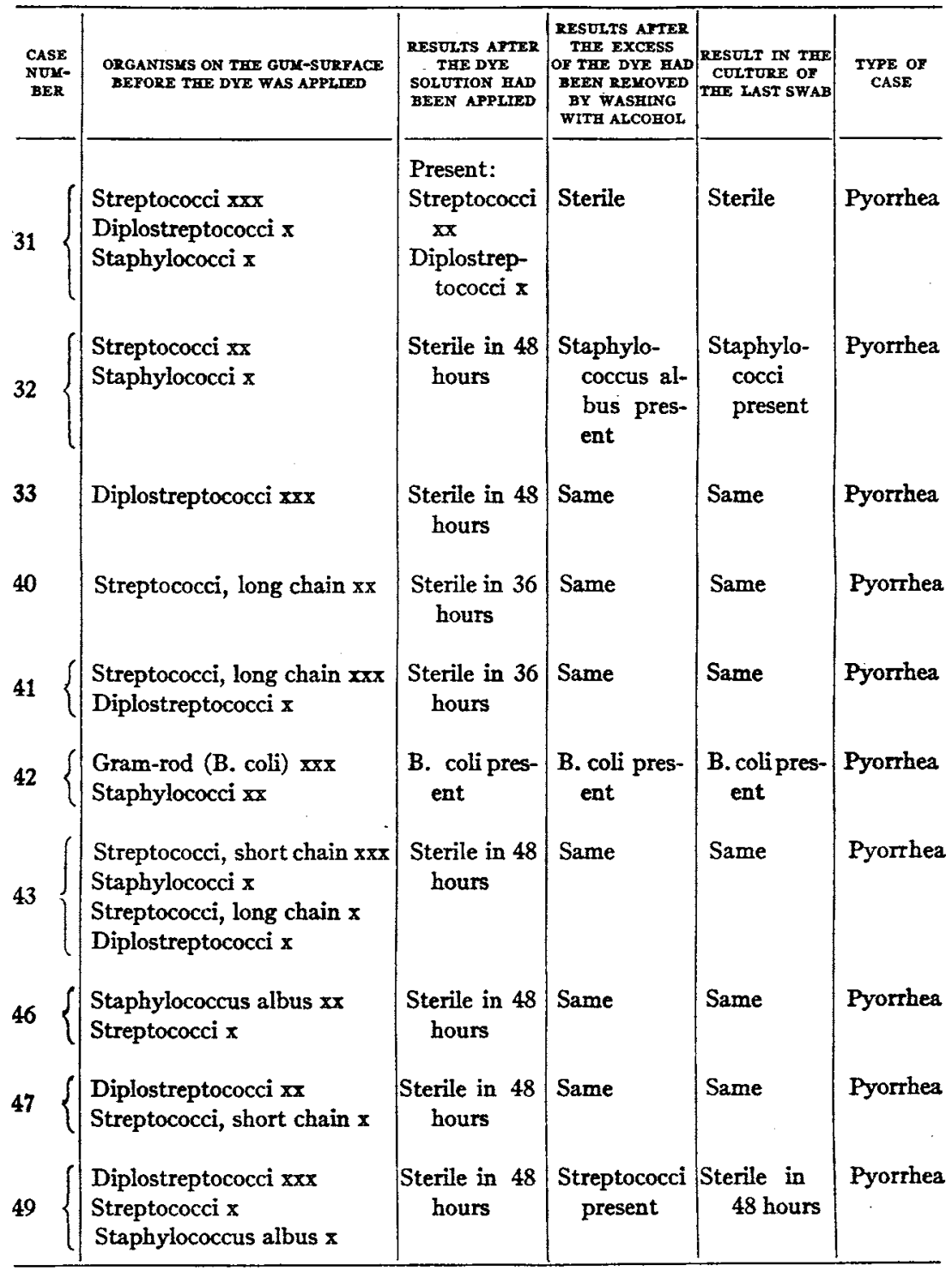

Total number of cases, 10 . Sterility in the number of cases indicated below:

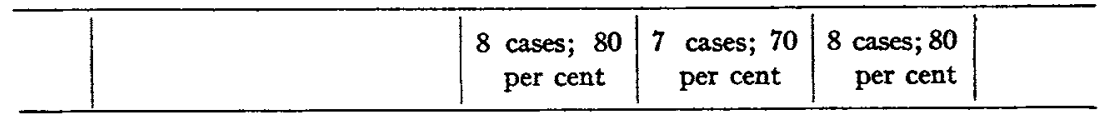


TABLE 6

Data on the comparative efficiency of crystal violet and brilliant green together (1 per cent of each) and of hydroquinone (1 per cent) in aqueaus solution, in efforts to obtain sterility in the buccal cavity. Periods of application to the gum: (a) crystal violet and brilliant green, 2 minutes, or 2.5 mimutes; $(b)$ hydroquinone, 2.25 minutes. Type of cases: all pyorthea

\begin{tabular}{|c|c|c|c|c|c|c|}
\hline $\begin{array}{l}\text { CASE } \\
\text { NUM- } \\
\text { BER }\end{array}$ & $\begin{array}{l}\text { ORGANISYS ON THE } \\
\text { GUY-SURFACE BEFORE THE } \\
\text { DYE WAS APPLITED }\end{array}$ & $\begin{array}{c}\text { RESULTS } \\
\text { AFTER THE } \\
\text { DYE SOLUTION } \\
\text { HAD BEEN } \\
\text { APPLIED FOR } \\
2 \text { XINOTES }\end{array}$ & $\begin{array}{c}\text { RESULT } \\
\text { DN THE LAST } \\
\text { CORRESPOND- } \\
\text { ING SWAB } \\
\text { CULTURE }\end{array}$ & $\begin{array}{c}\text { RESUITS } \\
\text { AFTER THE } \\
\text { DYE SÖLTTION } \\
\text { KAD BEEN } \\
\text { APPLIED FOX } \\
2.5 \text { YENUTES }\end{array}$ & $\begin{array}{l}\text { RESULT } \\
\text { NN THE IAST } \\
\text { CORERSPOAN- } \\
\text { ING SWAB } \\
\text { CULTURE }\end{array}$ & \begin{tabular}{|} 
RESUITS \\
ATTER TEE \\
HYDRO- \\
QUNONO SO- \\
LUTYON HAD \\
BEEN APPLIED \\
FOR 2.25 \\
MTNUTRS
\end{tabular} \\
\hline 60 & $\begin{array}{l}\text { Streptococcus } x \times x \\
\text { Diplostreptococcus } x\end{array}$ & Same & Same & Same & Same & Same \\
\hline 61 & $\begin{array}{l}\text { Streptococcus xx } \\
\text { Diplostreptococcus } \mathrm{x} \\
\text { Staphylococcus albus } \mathrm{x}\end{array}$ & $\begin{array}{l}\text { Strepto- } \\
\text { coccus } \\
\text { present }\end{array}$ & $\begin{array}{l}\text { Present: } \\
\text { Strepto- } \\
\text { coccus } \\
\text { xx } \\
\text { Diplo- } \\
\text { strepto- } \\
\text { coccus } x\end{array}$ & $\begin{array}{l}\text { Strepto- } \\
\text { coccus } \\
\text { present }\end{array}$ & $\begin{array}{l}\text { Strepto- } \\
\text { coccus } \\
\text { present }\end{array}$ & $\begin{array}{c}\text { Same as } \\
\text { control } \\
\text { (first } \\
\text { column) }\end{array}$ \\
\hline 62 & $\begin{array}{l}\text { Streptococcus x } \\
\text { Diplostreptococcus x }\end{array}$ & Same & Same & Same & Same & Same \\
\hline 63 & $\begin{array}{l}\text { Staphylococcus } x x x \\
\text { Streptococcus } x x\end{array}$ & $\begin{array}{l}\text { Strepto- } \\
\text { coccus } \\
\text { present }\end{array}$ & $\begin{array}{l}\text { Present: } \\
\text { Strepto- } \\
\text { coccus xx } \\
\text { Staphylo- } \\
\text { coccus } x\end{array}$ & $\begin{array}{l}\text { Strepto- } \\
\text { coccus } \\
\text { present }\end{array}$ & $\begin{array}{l}\text { Strepto- } \\
\text { coccus } \\
\text { present }\end{array}$ & $\begin{array}{c}\text { Same as } \\
\text { control } \\
\text { (first } \\
\text { column) }\end{array}$ \\
\hline 64\{ & $\begin{array}{l}\text { Streptococcus xx } \\
\text { B. coli } x\end{array}$ & Same & Same & Same & Same & Same \\
\hline 65 & Streptococcus & Same & Same & Same & Same & Same \\
\hline 66\{ & $\begin{array}{l}\text { Streptococcus } \mathrm{xx} \\
\text { Staphylococcus } \mathrm{xx} \\
\text { Diplostreptococcus } \mathrm{x}\end{array}$ & $\begin{array}{l}\text { Present: } \\
\text { Strepto- } \\
\text { coccus } x \\
\text { Staphylo- } \\
\text { coccus } x\end{array}$ & $\begin{array}{l}\text { Present: } \\
\text { Strepto- } \\
\text { coccus } x \\
\text { Staphylo- } \\
\text { coccus x } \\
\text { Diplo- } \\
\text { strepto- } \\
\text { coccus } x\end{array}$ & $\begin{array}{l}\text { Present: } \\
\text { Strepto- } \\
\text { coccus } x \\
\text { Staphylo- } \\
\text { coccus } x\end{array}$ & Same & $\begin{array}{l}\text { Same as } \\
\text { control } \\
\text { (first } \\
\text { column) }\end{array}$ \\
\hline 67 & $\begin{array}{l}\text { Staphylococcus } x \mathbf{x} \\
\text { Streptococcus } \mathrm{x}\end{array}$ & Same & Same & Same & Same & Same \\
\hline
\end{tabular}


TABLE 6-Concluded

\begin{tabular}{|c|c|c|c|c|c|c|}
\hline $\begin{array}{c}\text { CASE } \\
\text { NUM- } \\
\text { BER }\end{array}$ & $\begin{array}{l}\text { ORGANISMS ON THE } \\
\text { GUY-SURPACE BEFORE THE } \\
\text { DYE WAS APPLIED }\end{array}$ & $\begin{array}{c}\text { RESULTS } \\
\text { AFTER THE } \\
\text { DYE SOLUTION } \\
\text { HAD BEEN } \\
\text { APPIIED FOR } \\
2 \text { MTNUTES }\end{array}$ & $\begin{array}{c}\text { RESULT } \\
\text { IN THE, ILAST } \\
\text { CORRESPOND- } \\
\text { ING SWAB } \\
\text { CULTURE }\end{array}$ & $\begin{array}{c}\text { RESULTS } \\
\text { AFTER THE } \\
\text { DYE SOLUTION } \\
\text { HAD BEEN } \\
\text { APPLIED FOR } \\
2.5 \text { YENUTES }\end{array}$ & $\begin{array}{c}\text { RESULT } \\
\text { IN THE LAST } \\
\text { CORRESPOND } \\
\text { ING SWAB } \\
\text { CULTURE }\end{array}$ & \begin{tabular}{|} 
RESULTS \\
AFTER THE \\
HYDRO- \\
QUNONE SO- \\
LUTION BAD \\
BEEN APPI,YED \\
FOR 2.25 \\
YTNUTES
\end{tabular} \\
\hline 68 & $\begin{array}{l}\text { Diplostreptococcus xx } \\
\text { Streptococcus } \mathrm{x}\end{array}$ & Same & Same & Same & Same & Same \\
\hline 69 & $\begin{array}{l}\text { Streptococcus } \mathrm{xx} \\
\text { B. coli xx } \\
\text { Diplostreptococcus } \mathrm{x} \\
\text { Staphylococcus } \mathrm{x}\end{array}$ & Same & Same & $\begin{array}{l}\text { Present: } \\
\text { Strepto- } \\
\text { coccus } \\
\mathbf{x x} \\
\text { B. coli xx } \\
\text { Diplo- } \\
\text { strepto- } \\
\text { coccus } \mathbf{x}\end{array}$ & Same & $\begin{array}{l}\text { Same as. } \\
\text { control } \\
\text { (first } \\
\text { column) }\end{array}$ \\
\hline
\end{tabular}

G. Results of tests with brilliant green and crystal violet in solution together (1 per cent of each in aqueous solution) compared with hydroquinone (1 per cent aqueous solution)

At this stage we considered it advisable to ascertain the relative value of an aqueous solution of the dyes compared with an aqueous solution of hydroquinone. Accordingly we made a solution of brilliant green and crystal violet (1 per cent of each, together), and another of hydroquinone ( 1 per cent), in sterile distilled water. The bacteriological technique was the same as that outlined for the tests in section F.

The results, as shown in table 6; were wholly unsatisfactory, from an experimental point of view, for practically no sterility was obtained under the conditions of the tests.

H. Results of a repetition of the tests with brilliant green and crystal violet in solution together in alcohol (section $\mathrm{E}$ ), with an extension of the period of application to the gum (from 1.5 minute) to 2 minutes

We repeated the technique of the tests in section $\mathrm{E}$ (with 1 per cent each of brilliant green and crystal violet together in solution in $\mathbf{5 0}$ per cent alcohol), but allowed a little more time for the action of the 
TABLE 7

Additional data on the efficiency of crystal violet and brilliant green together (1 per cent of each), in 50 per cent alcohol, in efforts to obtain sterility in the buccal cavity. Period of application to the gum: 2 minutes

\begin{tabular}{|c|c|c|c|c|}
\hline $\begin{array}{l}\text { CASE } \\
\text { NUXEER }\end{array}$ & $\begin{array}{c}\text { ORGANISUS ON, THE GOY-SURTACE BEFORE } \\
\text { THE DYE WAS APPLIED }\end{array}$ & $\begin{array}{l}\text { DESULTS AFTER THE } \\
\text { DYK SOLUTIOK } \\
\text { EAD BEEN APPLIED }\end{array}$ & $\begin{array}{l}\text { RFsULT DN THE } \\
\text { OS COLTUNI OF } \\
\text { IHE LAST SWAB }\end{array}$ & $\begin{array}{l}\text { TYPES OT } \\
\text { CASES }\end{array}$ \\
\hline $65 / 2$ & $\begin{array}{l}\text { Streptococcus xx } \\
\text { Diplostreptococcus } \mathbf{x}\end{array}$ & $\begin{array}{l}\text { Sterile in } 48 \\
\text { hours }\end{array}$ & $\begin{array}{l}\text { Sterile in } 48 \\
\text { hours }\end{array}$ & Pyorrhea \\
\hline $66 / 2$ & Streptococcus & $\begin{array}{l}\text { Sterile in } 48 \\
\text { hours }\end{array}$ & $\begin{array}{l}\text { Sterile in } 48 \\
\text { hours }\end{array}$ & Pyorrhea \\
\hline $67 / 2$ & $\begin{array}{l}\text { Diplostreptococcus } \mathbf{x x} \\
\text { Streptococcus }\end{array}$ & $\begin{array}{l}\text { Sterile in } 48 \\
\text { hours }\end{array}$ & $\begin{array}{l}\text { Sterile in } 48 \\
\text { hours }\end{array}$ & $\begin{array}{l}\text { Pyorrhea } \\
\text { and ca- } \\
\text { ries }\end{array}$ \\
\hline $68 / 2$ & $\begin{array}{l}\text { Staphylococcus albus } x x \\
\text { Streptococcus } x\end{array}$ & $\begin{array}{l}\text { Sterile in } 48 \\
\text { hours }\end{array}$ & $\underset{\text { hours }}{\text { Sterile in } 48}$ & Pyorrhea \\
\hline $69 / 2$ & Streptococcus & $\begin{array}{l}\text { Sterile in } 48 \\
\text { hours }\end{array}$ & $\begin{array}{l}\text { Sterile in } 48 \\
\text { hours }\end{array}$ & $\begin{array}{l}\text { Edentu- } \\
\text { lous }\end{array}$ \\
\hline 70 & $\begin{array}{l}\text { Diplostreptococcus } x \\
\text { Staphylococcus } x\end{array}$ & $\begin{array}{l}\text { Sterile in } 48 \\
\text { hours }\end{array}$ & $\begin{array}{l}\text { Sterile in } 48 \\
\text { hours }\end{array}$ & Pyorrhea \\
\hline 71 & $\begin{array}{l}\text { Diplostreptococcus xx } \\
\text { Streptococcus } x \\
\text { Staphylococcus albus x }\end{array}$ & $\begin{array}{l}\text { Sterile in } 48 \\
\text { hours }\end{array}$ & $\begin{array}{l}\text { Sterile in } 48 \\
\text { hours }\end{array}$ & Pyorrbea \\
\hline 72 & $\begin{array}{l}\text { Streptococcus, long chain } x x \\
\text { Streptococcus, short chain } x x \\
\text { Staphylococcus } x \\
\text { Diplostreptococcus } x\end{array}$ & $\begin{array}{l}\text { Streptococcus, } \\
\text { long chain, } \\
\text { present }\end{array}$ & $\begin{array}{l}\text { Streptococcus, } \\
\text { long chain, } \\
\text { present }\end{array}$ & Pyorrhea \\
\hline 73 & Staphylococcus albus & $\begin{array}{l}\text { Sterile in } 48 \\
\text { hours }\end{array}$ & $\begin{array}{c}\text { Sterile in } 48 \\
\text { hours }\end{array}$ & Pyorrhea \\
\hline$\cdot 75$ & $\begin{array}{l}\text { Streptococcus } x \\
\text { Diplostreptococcus } x\end{array}$ & $\begin{array}{l}\text { Sterile in } 48 \\
\text { hours }\end{array}$ & $\begin{array}{c}\text { Sterile in } 48 \\
\text { hours }\end{array}$ & Pyorrhea \\
\hline 76 & $\begin{array}{l}\text { Diplostreptococeus } x x \\
\text { Staphylococcus } x\end{array}$ & $\begin{array}{l}\text { Sterile in } 48 \\
\text { hours }\end{array}$ & $\begin{array}{l}\text { Sterile in } 48 \\
\text { hours }\end{array}$ & Pyorrhea \\
\hline 77 & $\begin{array}{l}\text { Diplostreptococcus } \mathbf{x x} \\
\text { Staphylococcus } x \\
\text { Streptococcus, long chain } x\end{array}$ & $\begin{array}{l}\text { Sterile in } 48 \\
\text { hours }\end{array}$ & $\begin{array}{c}\text { Sterile in } 48 \\
\text { hours }\end{array}$ & Pyorrhea \\
\hline
\end{tabular}


TABLE 7-Continued

\begin{tabular}{|c|c|c|c|c|}
\hline $\begin{array}{l}\text { CASE } \\
\text { NUYBER }\end{array}$ & $\begin{array}{l}\text { ORGANISYS ON THE GUY-SURFACE BEFORX } \\
\text { THE DYE WAS APPLIED }\end{array}$ & $\begin{array}{l}\text { RESULTS AFTER TBE } \\
\text { DYE SOLUTION } \\
\text { HAD BEEN APPLTED }\end{array}$ & $\begin{array}{l}\text { RESULT IN THE } \\
\text { CULTURE OF } \\
\text { THE LAST SWAB }\end{array}$ & $\begin{array}{l}\text { TYPE OF } \\
\text { CASES }\end{array}$ \\
\hline 78 & $\begin{array}{l}\text { Streptococcus xxxx } \\
\text { Diplostreptococcus } x\end{array}$ & $\begin{array}{l}\text { Sterile in } 48 \\
\text { hours }\end{array}$ & $\begin{array}{l}\text { Sterile in } 48 \\
\text { hours }\end{array}$ & $\begin{array}{l}\text { Pyorrhea } \\
\text { and ca- } \\
\text { ries }\end{array}$ \\
\hline 79 & $\begin{array}{l}\text { Streptococcus } \mathrm{xx} \\
\text { Staphylecoccus albus } \mathrm{x} \\
\text { Diplostreptococcus } \mathrm{x}\end{array}$ & $\begin{array}{l}\text { Staphylococ- } \\
\text { cus albus } \\
\text { present }\end{array}$ & $\begin{array}{l}\text { Staphylococ- } \\
\text { cus albus } \\
\text { present }\end{array}$ & Pyorrhea \\
\hline 80 & Streptococcus, long chain & Sterile & Sterile & $\begin{array}{l}\text { Edentu- } \\
\text { lous }\end{array}$ \\
\hline 81 & $\begin{array}{l}\text { Diplostreptococcus } \mathrm{xx} \\
\text { Streptococcus } \mathrm{x}\end{array}$ & Sterile & Sterile & $\begin{array}{l}\text { Advanced } \\
\text { caries }\end{array}$ \\
\hline 85 & $\begin{array}{l}\text { Staphylococcus albus } \mathrm{x} \\
\text { Diplostreptococcus } \mathrm{x}\end{array}$ & Sterile & Sterile & Pyorrhea \\
\hline 86 & $\begin{array}{l}\text { Streptococcus xxx } \\
\text { Diplostreptococcus x }\end{array}$ & Sterile & Sterile & Pyorrhea \\
\hline 87 & $\begin{array}{l}\text { Diplostreptococcus xx } \\
\text { Streptococcus } \mathrm{x} \\
\text { Staphylococcus albus } \mathrm{x}\end{array}$ & Sterile & Sterile & Pyorrhea \\
\hline 88 & $\begin{array}{l}\text { Staphylococcus albus } \mathrm{xx} \\
\text { Streptococcus } \mathrm{x}\end{array}$ & Sterile & $\begin{array}{l}\text { Staphylococ- } \\
\text { cus albus } \\
\text { present }\end{array}$ & Pyorrhea \\
\hline 89 & Streptococcus & Sterile & Sterile & Pyorrhea \\
\hline 90 & $\begin{array}{l}\text { Diplostreptococcus } \mathrm{xx} \\
\text { Streptococcus } \mathrm{x}\end{array}$ & Sterile & Sterile & Pyorrhea \\
\hline 92 & $\begin{array}{l}\text { Streptococcus, long chain } \times x \\
\text { Streptococcus, short chain } x \\
\text { Staphylococcus albus } x\end{array}$ & Sterile & Sterile & $\begin{array}{l}\text { Fairly } \\
\text { clean } \\
\text { mouth }\end{array}$ \\
\hline 93 & $\begin{array}{l}\text { Diplostreptococcus xxx } \\
\text { Streptococcus } \mathbf{x}\end{array}$ & $\begin{array}{c}\text { Sterile in } 48 \\
\text { hours }\end{array}$ & $\begin{array}{l}\text { Sterile in } 48 \\
\text { hours }\end{array}$ & Pyorrhea \\
\hline 94 & Diplostreptococcus & $\begin{array}{l}\text { Sterile in } 48 \\
\text { hours }\end{array}$ & $\begin{array}{l}\text { Sterile in } 48 \\
\text { hours }\end{array}$ & Pyorrhea \\
\hline
\end{tabular}


TABLE 7-Concluded

\begin{tabular}{|c|c|c|c|c|}
\hline $\begin{array}{l}\text { CASE } \\
\text { NOMRER }\end{array}$ & $\begin{array}{l}\text { ORGAMTSUS ON THE GUM-SURPACE BERORE } \\
\text { THE DYE WAS APPLED }\end{array}$ & $\begin{array}{l}\text { RESURTS APTER THE } \\
\text { DXE SOLUTYON } \\
\text { HAD BEEN APPLIED }\end{array}$ & $\begin{array}{l}\text { RESUTTS IN THE } \\
\text { CULTURE OF } \\
\text { THE LAST SWAB }\end{array}$ & $\begin{array}{l}\text { TYPES Or } \\
\text { CASES }\end{array}$ \\
\hline 95 & $\begin{array}{l}\text { Streptococcus } \mathrm{xxx} \\
\text { Staphylococcus } \mathrm{xx} \\
\text { Diplostreptococcus } \mathrm{x}\end{array}$ & $\begin{array}{l}\text { Sterile in } 48 \\
\text { hours }\end{array}$ & $\begin{array}{c}\text { Sterile in } 48 \\
\text { hours }\end{array}$ & Pyorrhea \\
\hline 96 & $\begin{array}{l}\text { Streptococcus } x \\
\text { Diplostreptococcus } x\end{array}$ & $\begin{array}{l}\text { Sterile in } 48 \\
\text { hours }\end{array}$ & $\begin{array}{l}\text { Sterile in } 48 \\
\text { hours }\end{array}$ & Pyorrhea \\
\hline 97 & $\begin{array}{l}\text { Staphylococcus albus } x x \\
\text { Streptococcus } x\end{array}$ & $\begin{array}{l}\text { Sterile in } 48 \\
\text { hours }\end{array}$ & $\begin{array}{c}\text { Sterile in } 48 \\
\text { hours }\end{array}$ & Pyorrhea \\
\hline 98 & $\begin{array}{l}\text { Streptococcus } \mathrm{xxx} \\
\text { Diplostreptococcus } \mathrm{xx}\end{array}$ & $\begin{array}{l}\text { Streptococcus } \\
\text { present }\end{array}$ & $\begin{array}{l}\text { Streptococcus } \\
\text { present }\end{array}$ & Pyorrbea \\
\hline 99 & $\begin{array}{l}\text { Diplostreptococcus xx } \\
\text { Streptococcus } \mathrm{x}\end{array}$ & $\begin{array}{l}\text { Streptococcus } \\
\text { present }\end{array}$ & $\begin{array}{l}\text { Streptococcus } \\
\text { present }\end{array}$ & Pyorrhea \\
\hline 101 & $\begin{array}{l}\text { Streptococcus } \mathrm{x} \\
\text { Staphylococcus albus } \mathrm{x}\end{array}$ & $\begin{array}{l}\text { Streptococcus } \\
\text { present }\end{array}$ & $\begin{array}{l}\text { Streptococcus } \\
\text { present }\end{array}$ & Pyorrhea \\
\hline 102 & Streptococcus & $\begin{array}{l}\text { Streptococcus } \\
\text { present }\end{array}$ & $\begin{array}{l}\text { Streptococcus } \\
\text { present }\end{array}$ & Pyorrhea \\
\hline 103 & $\begin{array}{l}\text { Streptococcus xx } \\
\text { Diplostreptococcus x }\end{array}$ & $\begin{array}{l}\text { Streptococcus } \\
\text { present }\end{array}$ & $\begin{array}{l}\text { Streptococcus } \\
\text { present }\end{array}$ & Pyorrhea \\
\hline 104 & $\begin{array}{l}\text { Diplostreptococcus } \mathrm{xxx} \\
\text { Staphylococcus albus } \mathrm{x} \\
\text { Streptococcus } \mathrm{x} \\
\text { B. coli } \mathrm{xx}\end{array}$ & B. coli present & B. coli present & Pyorrhea \\
\hline 105 & $\begin{array}{l}\text { Streptococcus } \mathbf{x x} \\
\text { Staphylococcus albus } \mathbf{x}\end{array}$ & Sterile & Sterile & Pyorrhea \\
\hline 106 & $\begin{array}{l}\text { Streptococcus } x x x \\
\text { Staphylococcus albus } x x\end{array}$ & Sterile & Sterile & Pyorrhea \\
\hline 108 & $\begin{array}{l}\text { Diplostreptococcus xxx } \\
\text { Streptococcus } x\end{array}$ & Sterile & Sterile & Pyorrhea \\
\hline
\end{tabular}


dye, namely, 2 minutes instead of 1.5 minute. The results in table 7 are summarized below:

\begin{tabular}{|c|c|}
\hline Total number of cases cultured & $\begin{array}{c}\text { Number } \\
37\end{array}$ \\
\hline Sterile after application of the dye for two minutes.... & 33 \\
\hline Sterile swabs $\ldots \ldots \ldots \ldots \ldots \ldots \ldots \ldots \ldots \ldots \ldots \ldots \ldots$ & 32 \\
\hline Staphylococcus persisted after the application of the dye... & 1 \\
\hline Streptococcus persisted after the application of the dye..... & 1 \\
\hline
\end{tabular}

In this series of tests, and in those of the preceding groups, we noted that B. coli was not affected by the dye to any appreciable extent. We endeavored, then, to ascertain the comparative effects of the dye on B. coli and on a streptococcus. See the experiment described in the footnote. ${ }^{4}$

4 The supernatant fluid from a $100 \mathrm{cc}$. glucose-blood veal-broth culture of a streptococcus isolated from an apical infection was carefully pipetted off and centrifuged. The organisms thus obtained were suspended in normal salt solution and half their number, 500 billions, injected into the ear veins of a rabbit. The rabbit was sacrificed in ten minutes, immediately placed in 1:1000 lysol solution, and carefully autopsied. Portions of the liver, lungs, heart, and kidneys were obtained aseptically and placed in sterile petri dishes. Several pieces of each of these tissues, $0.5 \times 0.5 \times 1 \mathrm{~cm}$. in size, were dipped into a suspension of $\mathrm{B}$. coli. One of these pieces was then immersed for five seconds in paraffin oil at $180^{\circ} \mathrm{C}$., when it was macerater in a sterile mortar in broth and sand, and plated in glucose-blood agar; also in Endo's medium according to the method of McMaster (16). Others of the pieces treated with B. coli were dipped in a solution of brilliant green and crystal violet together ( 1 per cent each) in 50 per cent alcohol for 1.5 minute and the excess of the dye washed off with 50 per cent alcohol for 0.5 minute. The tissue was finally macerated as in the case of the pieces immersed in paraffin oil, with the following results:

\begin{tabular}{|c|c|c|c|c|}
\hline \multirow{2}{*}{$\begin{array}{l}\text { TISSUE TREATED } \\
\text { WITH B. COLI } \\
\end{array}$} & \multicolumn{2}{|c|}{$\begin{array}{l}\text { AFTER IMMERSION IN PARAFFIN OIL AT } \\
180^{\circ} \mathrm{C} \text {. FOR } 5 \text { SECONDS }\end{array}$} & \multicolumn{2}{|c|}{$\begin{array}{l}\text { AFTER APPLICATION OF THE DYE SOLDTHON } \\
\text { CRYSTAL VIOLET AND BRILLLANT GREEN } \\
\text { TOGETHER ( } 1 \text { PER CENT OF EACH) IN } 50 \\
\text { PER CENT ALCOHOL, POR } 1.5 \text { MINUTE } \\
\text { FOLLOWED BY WASHING WTTH } 50 \text { PER } \\
\text { CENT ALCOHOI, POR } 0.5 \text { MCNUTE }\end{array}$} \\
\hline & $\begin{array}{c}\text { Organisms in Endo's } \\
\text { medium }\end{array}$ & $\begin{array}{l}\text { Organisms in the } \\
\text { glucose-blood broth }\end{array}$ & $\underset{\text { medium }}{\text { Organisms in Endo's }}$ & $\begin{array}{l}\text { Organisms in the } \\
\text { glucose-blood broth }\end{array}$ \\
\hline Heart.. & No growth & Streptococci & B. coli & $\begin{array}{l}\text { Streptococci and } \\
\text { B. coli }\end{array}$ \\
\hline Kidney & No growth & Streptococci & B. coli & $\begin{array}{l}\text { Streptococci and } \\
\text { B. coli }\end{array}$ \\
\hline Lungs & No growth & Streptococci & No growth & Streptococci \\
\hline Liver....... & No growth & Streptococci & No growth & Streptococci \\
\hline
\end{tabular}

These tests show that in the second case, i.e., with the dye, there was no growth of B. coli in the cultures from the lungs and liver, possibly because of the better penetration of the dye into the lungs and liver, as a consequence of the peculiarities of the anatomical structure of these tissues. 
I. Results of a repetition of the tests with brilliant green and crystal violet together in alcohol, in the last preceding section $(\mathrm{H})$, after previous thorough flushing of the mouth with an alkaline wash and brushing of the teeth

After carefully flushing the mouth with an alkaline wash and brushing the teeth, the technique for the tests in section $\mathrm{H}$ was used, with the results shown in table 8 .

TABLE 8

Additional data on the efficiency of crystal violet and brilliant green together (1 per cent of each), in 50 per cent alcohol, in efforts to obtain sterility in the buccal cavity. Period of application to the gum: 2 minutes (after flushing the mouth with an alkaline wash and brushing the teeth)

\begin{tabular}{|c|c|c|c|c|}
\hline $\begin{array}{c}\text { CASE } \\
\text { NUTCBER }\end{array}$ & $\begin{array}{l}\text { ORGANISYS ON THE GOM-SURFACE } \\
\text { BEPORE THE DYE WAS APPLIED }\end{array}$ & $\begin{array}{l}\text { RESULTS AFTER THE } \\
\text { DYE SOLUTION } \\
\text { HAD BEEN APPLIED }\end{array}$ & $\begin{array}{l}\text { RESULT IN THE } \\
\text { CULTURE OF } \\
\text { THE IAST SWAB }\end{array}$ & TYPES OP CASES \\
\hline 110 & Streptococcus & Sterile & Sterile & Pyorrhea \\
\hline 111 & Streptococcus & Sterile & Sterile & Pyorrhea \\
\hline 112 & Staphylococcus & Sterile & Sterile & Pyorrhea \\
\hline 113 & $\begin{array}{l}\text { Streptococcus } \mathrm{x} \\
\text { Diplostreptococcus }\end{array}$ & Sterile & Sterile & Pyorrhea \\
\hline 114 & Streptococcus & Sterile & Sterile & Pyorrhea \\
\hline 115 & Diplostreptococcus & Sterile & Sterile & Pyorrhea \\
\hline 116 & $\begin{array}{l}\text { Diplostreptococcus } x x \\
\text { Streptococcus } x\end{array}$ & Sterile & Sterile & $\begin{array}{l}\text { Extensive } \\
\text { caries }\end{array}$ \\
\hline 117 & Diplostreptococcus & Sterile & Sterile & Pyorrhea \\
\hline 118 & Streptococcus & $\begin{array}{l}\text { Streptococcus } \\
\text { present }\end{array}$ & Sterile & Pyorrhea \\
\hline 119 & $\begin{array}{l}\text { Diplostreptococcus } \mathrm{xx} \\
\text { Streptococcus } \mathrm{x}\end{array}$ & Sterile & Sterile & Pyorrhea \\
\hline 120 & Staphylococcus & Sterile & Sterile & Pyorrhea \\
\hline 121 & $\begin{array}{l}\text { Streptococcus xxx } \\
\text { Diplostreptococcus } \mathrm{x}\end{array}$ & Sterile & Sterile & Pyorrhea \\
\hline 122 & Streptococcus & Sterile & Sterile & Pyorrhea \\
\hline 123 & $\begin{array}{l}\text { Streptococcus, long chain } x \\
\text { Streptococcus, short chain } x\end{array}$ & Sterile & Sterile & Pyorrhea \\
\hline
\end{tabular}

Total number of cases: 14; sterility in 13 cases, or 92 per cent; absolute sterility in 14 cases or 100 per cent.

\section{General discussion of the results of the first two series of tests}

Alcohol and iodine should be rejected as oral antiseptics on account of their harmful effects on the delicate mucous membrane despite their apparently good qualities as antiseptics elsewhere. 
Since neither crystal violet nor brilliant green is much affected by the oral secretions, and as the action of each is enhanced by the slight alkalinity of the saliva, we regard these dyes as excellent oral antiseptics, in accord with the findings recorded in sections $\mathrm{D}, \mathrm{E}, \mathrm{F}, \mathrm{H}$, and $I$ above.

The results of the tests described in section I, show that advantage may be derived from a thorough cleansing of the mouth and teeth before applying the antiseptic. The alkaline mouth-wash employed in the tests for this purpose appears to have been responsible for the improvement of the results (I).

\section{Third series. Clinical findings}

The results of the foregoing experiments show the efficiency of dyes as antiseptics from the laboratory view-point. Consequently, we endeavored to ascertain their value from the clinical and therapeutic aspects.

The following case histories have been selected from a very large number to illustrate the effects of practical application, in dental surgery, of crystal violet and brilliant green in solution together (1 per cent of each in 50 per cent alcohol), referred to below as "the dye."

Case 1. Mr. J. A. An extensive bone cyst in the mandible. It was opened, curretted, drained, and treated with the dye. The discharge, which had been profuse and purulent, became scanty and serous after two applications with a one-day interval. Granulations began to grow inward from all sides. The wound gradually closed up in four weeks of this treatment.

Case 2. Mr.M.S. A rather large granuloma, and surrounding infected bone, was incised, curretted, drained, and treated with the dye. Granulations grew rapidly and healing was by first intention.

Case 3. Mr.J.F. An osteomyelitis of the lower third of a fibula. It was opened, drained, and treated with camphor-phenol for one month without improvement and with a continuing profuse, purulent, foul discharge. The dye was applied and the discharge soon became scanty, serous and odorless. Two small sequestra were recently removed. Healing began promptly after the operation and is proceeding rapidly. 
Case 4. Mrs. J. A surgical removal of granulomata and the surrounding necrotic bone. The wound was treated with the dye. Healing took place promptly, with no discharge save in one area, which is yielding rapidly to treatment with the dye.

Case 5. Mr. J.H. A severe case of pyorrhea. Teeth were removed. The wounds were treated with the dye three times. There has been no history of pain or soreness. Healing progressed at a rapid rate.

Case 6. Mrs. B. Extensive apical and periapical infections. Teeth were surgically removed. The wounds were treated once weekly, for three weeks, with the dye. Healing was complete with almost no discharge. Dentures were constructed in the third week after the extractions.

Case 7. Mr. R. A superior first molar was removed surgically under local anesthesia. A severe case of eburnated bone. Treated twice with the dye. Healing was complete in five days, with no discharge.

Case 8. Miss C. Granulomata and necrosis about lower first and second molars. "These were removed under local anesthesia, with extensive currettage. The wounds were treated daily, for a week, with the dye. There were slight, scanty, serous discharges, but no pain. The wounds were completely healed in three weeks.

Many other cases might be mentioned, in which the results were quite similar. In the research laboratories and clinics of the dental department a large number of patients have been treated with the dye. The histories of these cases appear to confirm the general deduction stated above regarding the antiseptic value of the dye. The improvement in cases of chronic gingivitis has been very marked. Injection of the dye into pyorrheal pockets is of only temporary benefit, however, for the tendency toward tissue degeneration is not noticeably altered.

\section{Discussion of the clinical findings}

Solutions of crystal violet and brilliant green may be easily applied to the gums and even deeper structures in the oral cavity. The diffusion and penetration of the dye is considerable. The clinical data reported above are wholly in keeping with the results that various observers have obtained with dyes as antiseptics for other parts of the body. In every instance, in our experience, the case was benefited by treatment with the dye. Extractions, old discharging sinuses and old infections, yield completely to treatment. 
Solutions of crystal violet and brilliant green appear to have no lasting beneficial effect upon pyorrhea. The only result we obtained was merely a temporary diminution in the severity of the symptoms.

\section{SUMMARY OF GENERAL CONCLUSIONS}

Brilliant green and crystal violet, in solution together (1 per cent of each in 50 per cent alcohol), are very efficient, mild antiseptics. This combination has very little, if any, harmful effect on the delicate mucous membrane of the mouth.

Clinical observations indicate that these dyes together in alcohol act not only as an antiseptic, but also as a mild stimulant to newly forming granulations, both by keeping down contamination by oral organisms and by either destroying or inhibiting the growth of organisms initially present.

We wish to express our gratitude to the following colleagues for their kind assistance in providing clinical material: W. A. Colburn, D.D.S., H. H. Markel, M.D., S. J. Ashby, D.D.S., Franklin W. McCormack, H. Tuckey, D.D.S., and S. Hardy, D.D.S.

\section{LITERATURE CITED}

(1) Brownnsg, C. H. 1918 Applied bacteriology Oxford Press, London, England.

(2) - AND BonNeY, V. 1918 Sterilization of the skin and other surfaces by a mixture of crystal violet and brilliant green. British Medical Journal, p. 562 (part 1).

(3) - AND Gulbransex, G. 1919 The testing of antiseptics in relation to their use in wound treatment. Journal of Bygiene, xviii, p. 33.

(4) —- Gulbransen, R., Kennaway, E. L., and Thornton, L. H. D. 1917 Flavine and brilliant green. British Medical Journal, p. 73 (part 1).

(5) - Gulbransen, R., and Trornton, L. H. D. 1917 The antiseptic properties of acriflavine and proflavine and brilliant green. British Medical Journal, p. 70 (part 2).

(6) Clark, W. M., AND LUBs, H. A. 1917 The colorimetric determination of hydrogen ion concentration and its application to bacteriology. Journal of Bacteriology, ii, p. 191.

(7) GILMER, T. L., AND Moody, A. M. 1914 A study of the bacteriology of alveolar abscess and infected root canals. Journal of the American Medical Association, lxiii, p. 2023.

(8) Graham-Surti, G. S. 1919 Some factors influencing the action of dyes and allied compounds on bacteria. Journal of Hygiene, xviii, p. 1.

(9) - $1919 \mathrm{New}$ and non-official remedies: acriflavine and proflavine. Journal of the American Medical Asseciation, lxxiii, p. 1443. 
(10) Hartzeli, T. B., AND HeNRici, A. T. 1915 Oral prophylaxis in its relation to pyorrhea and its treatment. Journal of the National Dental Association, ii, p. 122.

(11) HEAD, J., AND Roos, C. 1919 On the bacteriology of apical abscesses. Journal of Dental Research, i, p. 13.

(12) Howe, P. R. 1919 Dental foci. Dental Summary, xxxix, p. 793.

(13) KeLSEY, C. J. 1919 Oral bacteria exhibiting strepto-bacillary characters. British Dental Journal, xl, p. 373.

(14) Lerrch, A. 1916 Brilliant green as an antiseptic. British Medical Journal, p. 236 (part 1).

(15) Ligot, D. 1917 Flavine and brilliant green in the treatment of infected wounds. British Medical Journal, p. 73 (part 1).

(16) MCMAStER, P. D. 1919 The germicidal power of antiseptic oils and of substances dissolved in oils. Journal of Infectious Diseases, xxiv, p. 378.

(17) Macleod, J. J. R. 1919 The diagnosis of acidosis. Journal of Laboratory and Clinical Medicine, iv, p. 315.

(18) Marshaxl, John A. 1915 The neutralizing power of saliva in its relation to dental caries. American Journal of Physiology, xxxvi, p. 260.

(19) MeYer, K. F. 1917 The present status of dental bacteriology. Journal of the National Dental Association, iv, p. 966.

(20) Rosenow, E. C. 1919 Studies on elective localization. Focal infection, with special reference to oral sepsis. Journal of Dental Research, i, p. 205; also Journal of the National Dental Assaciation, vi, p. 983.

(21) Schamberg, M. I. 1914 Abstract of a discussion of a symposium on mouth infections. Journal of the American Medical Association, lxiii, p. 2029.

(22) Seelig, M. G., AND Goudd, C. W. 1911 Osmosis as an important factor in the action of antiseptics. Surgery, Gynecology and Obstetrics, xii, p. 262.

(23) Short, A. R., ARkie, J. S., ANd King, C. 1917 Report on wound treatment by brilliant green paste. British Medical Journal, p. 506 (part 2).

(24) Weвв, C. H. S. 1917 A note on the value of brilliant green as an antiseptic. British Medical Journal, p. 870 (part 1). 